agriTECH, 40 (3) 2020, 199-205

\title{
Penilaian Daya Dukung Sungai Antirogo di Kabupaten Jember terhadap Beban Pencemaran Menggunakan Metode Streeter-Phelps
}

\author{
Antirogo River Capacity Rating in Jember Regency Against Pollution Load Using the Streeter-Phelps \\ Sri Wahyuningsih, Elida Novita, Deni Agung Idayana* \\ Jurusan Teknik Pertanian, Fakultas Teknologi Pertanian, Universitas Jember \\ Jl. Kalimantan No. 37, Jember 68121, Indonesia \\ *Penulis korespondensi: Deni Agung Idayana, E-mail: deniagungidayana@gmail.com \\ Tanggal submisi: 8 Oktober 2019; Tanggal penerimaan: 14 Februari 2020
}

\begin{abstract}
ABSTRAK
Sungai Antirogo merupakan anak sungai dari DAS Bedadung yang terletak dari Kelurahan Tegal Gede hingga Kelurahan Sumbersari - Kecamatan Sumbersari, Kabupaten Jember - Jawa Timur. Beberapa penggunaan lahan yang terdapat di Sungai Antirogo antara lain pertanian, pemukiman penduduk, dan industri. Limbah dari penggunaan lahan tersebut bila dibuang ke sungai akan berdampak pada penurunan kualitas air. Tujuan dari penelitian ini adalah untuk mengetahui daya tampung sungai terhadap beban pencemaran menggunakan metode Streeter Phelps sesuai dengan Keputusan Menteri Negara Lingkungan Hidup Nomor 110 tahun 2003. Pengambilan sampel air Sungai Antirogo berada di empat titik pantau yaitu ATR01, ATR02, ATR03, dan ATR04 yang menggunakan metode purposive sampling method, kemudian dilakukan analisis kualitas air. Rata-rata nilai beban pencemaran Sungai Antirogo yaitu 70,37 kg/hari. Nilai beban pencemaran tertinggi berada pada titik ATR03 yaitu $81,04 \mathrm{~kg} /$ hari, sedangkan nilai beban pencemaran terendah berada pada titik ATR04 yaitu 64,81 kg/hari. Kemampuan sungai dapat diketahui dengan menghitung laju deoksigenasi, laju reaerasi, defisit oksigen kritis, jarak kritis, dan waktu yang diperlukan untuk mencapai titik kritis. Rata-rata laju deoksigenasi Sungai Antirogo yaitu 1,77 mg/L.hari dan rata-rata laju reaerasi yaitu $16,13 \mathrm{mg} / \mathrm{L}$.hari. Nilai DO act pada titik pantau ATR01, ATR02, ATR03, dan ATR04 berturut-turut yaitu $6,59 \mathrm{mg} / \mathrm{L}, 6,67 \mathrm{mg} / \mathrm{L}, 6,63 \mathrm{mg} / \mathrm{L}, 6,67 \mathrm{mg} / \mathrm{L}$. Nilai rata-rata defisit oksigen awal yaitu $1,19 \mathrm{mg} / \mathrm{L}$. Berdasarkan laju deoksigenasi, laju reaerasi, nilai defisit oksigen, dan nilai $\mathrm{DO}_{\text {act }}$ dapat dinyatakan bahwa Sungai Antirogo tidak mengalami kondisi kritis, dan masih mampu menampung beban pencemaran sebesar 7,26 kg/hari.
\end{abstract}

Kata kunci: Sungai Antirogo; daya tampung; deoksigenasi; reaerasi; streeter phelps

\begin{abstract}
The Antirogo River is a tributary of Bedadung Watershed which flows from Tegal Gede Village to Sumbersari Village, Jember Regency, East Java. The land areas near the River is used for agriculture, residential settlements, and industry. The wastes dumped from these lands degrades the water quality. Therefore, this study aimed to determine the river capacity against pollution loads, using the Streeter Phelps method in accordance with the Decree of Environment State Minister No. 110 of 2003. Water samples was taken from the River and divided into four monitoring points namely ATR01, ATR02, ATR03, and ATR04. A purposive sampling method was used and the water quality was analyzed. The average pollution load is $70.37 \mathrm{~kg} /$ day. Furthermore, the highest load is 81.04 $\mathrm{kg} /$ day at ATR03 and the lowest is $64.81 \mathrm{~kg} /$ day at ATR04. Therefore, the river's capacity can be determined by calculating the reaeration and deoxygenation rate, critical oxygen deficit, distance, and time taken to reach a point. The average deoxygenation rate is $1.77 \mathrm{mg} / \mathrm{L}$.day, and that of reaeration is $16.13 \mathrm{mg} / \mathrm{L}$.day. Also, the $\mathrm{DO}_{\text {act }}$
\end{abstract}

DOI: http://doi.org/10.22146/agritech.50450

ISSN 0216-0455 (Print), ISSN 2527-3825 (Online) 
values at ATR01, ATR02, ATR03, and ATR04 were $6.59 \mathrm{mg} / \mathrm{L}, 6.67 \mathrm{mg} / \mathrm{L}, 6.63 \mathrm{mg} / \mathrm{L}$, and $6.67 \mathrm{mg} / \mathrm{L}$ respectively. The average value of oxygen deficit is $1.19 \mathrm{mg} / \mathrm{L}$. According to the values of deoxygenation, reaeration, oxygen deficit, and $\mathrm{DO}_{\text {act }}$ it can be interpreted that the river is not in a critical condition, and, therefore, can tolerate pollutant load of $7.26 \mathrm{~kg} /$ day.

Keywords: Antirogo river; capacity; deoxygenation; reaeration; streeter phelps

\section{PENDAHULUAN}

Air merupakan sumberdaya alam yang berfungsi sebagai unsur paling esensial, penentu terpenting dalam kehidupan setiap makhluk hiidup. Pemanfaatan air untuk berbagai kepentingan harus dilakukan secara bijaksana dengan mempertimbangkan kepentingan generasi sekarang dan generasi mendatang (Darmasusantini dkk., 2015). Sungai merupakan salah satu komponen penting dalam kehidupan manusia. Peranan sungai di kehidupan sehari-hari yaitu untuk mengairi lahan pertanian dan untuk memenuhi kebutuhan air bersih bagi masyarakat. Seiring dengan bertambahnya jumlah penduduk setiap tahun, kebutuhan air bersih juga semakin meningkat. Namun, jumlah air bersih setiap tahunnya semakin berkurang dan sulit didapatkan. Apabila hal tersebut tidak ditangani dengan baik, maka akan berdampak buruk pada kualitas dan kuantitas air bersih.

Pertumbuhan penduduk yang semakin pesat dapat meningkatkan pemenuhan terhadap air bersih dan infrastruktur pendukung lainnya. Kuantitas dan kualitas air sungai di Kabupaten Jember telah menurun karena pencemaran yang mengakibatkan air bersih terbatas serta mengancam lingkungan estuari dan muara pada daerah hilir (Suma, 2018). Selain mengakibatkan air bersih menjadi terbatas dan mengancam lingkungan juga akan berdampak pada kemampuan daya tampung sungai terhadap beban pencemaran tersebut.

Berdasarkan Keputusan Menteri Negara Lingkungan Hidup (2003), pengurangan oksigen (deoksigenasi) adalah pengurangan oksigen yang terlarut dalam air perairan yang disebabkan oleh aktivitas bakteri mendegradasi zat organik. Proses deoksigenasi merupakan proses penting dalam upaya sungai melakukan self purification, yaitu mendegradasi polutan organik jenis bio-degradable agar sungai kembali bersih. Sedangkan reaerasi adalah proses penambahan oksigen di dalam air akibat turbulensi aliran yang menyebabkan perpindahan oksigen dari udara ke air (Keputusan Menteri Negara Lingkungan Hidup, 2003). Semakin deras dan dangkal suatu perairan, semakin besar angka konstanta kecepatan reaerasi dan sebaliknya (Astono, 2010)
Menurut Hastono (2007), defisit oksigen di sepanjang aliran sungai bisa berasal dari sumber pencemar titik dan sumber pencemar menyebar di dalam aliran seragam (uniform-flow) atau aliran tidak seragam (non uniform-flow). Konsentrasi di perairan terhadap fungsi jarak dan waktu digambarkan melalui kurva oksigen (DO Sag). Defisit oksigen kritis (DC) yaitu kondisi defisit DO terendah yang dicapai akibat beban yang diberikan aliran. Defisit oksigen terjadi akibat perbedaan nilai konsentrasi DO saturasi dan DO aktual.

Daya tampung beban pencemaran air adalah kemampuan air pada suatu sumber air untuk menerima masukan beban pencemaran tanpa mengakibatkan air tersebut menjadi cemar (Keputusan Menteri Negara Lingkungan Hidup, 2003). Tujuan dari penelitian ini adalah untuk mengetahui daya tampung sungai terhadap beban pencemaran menggunakan metode Streeter Phelps sesuai dengan Keputusan Menteri Negara Lingkungan Hidup Nomor 110 tahun 2003. Persamaan Streeter Phelps menggunakan dua fenomena yaitu proses pengurangan oksigen terlarut (deoksigenasi) akibat aktivitas bakteri dalam mendegradasikan bahan organik yang ada dalam air dan proses peningkatan oksigen terlarut (reaerasi) yang disebabkan turbulensi yang terjadi pada aliran sungai.

\section{METODE PENELITIAN}

Penelitian ini dilaksanakan pada bulan April hingga Mei 2019, tempat penelitian terbagi menjadi dua lokasi yaitu: 1) pengambilan sampel dilakukan dengan metode Grap Sampling atau metode pengambilan sesaat di empat titik lokasi Sungai Antirogo, Kelurahan Tegal Gede hingga Kelurahan Sumbersari, Kecamatan Sumbersari, Kabupaten Jember yang dapat dilihat dalam peta wilayah kajian pada Gambar 1. Penentuan titik menggunakan metode purposive sampling method yaitu pengambilan berdasarkan titik yang diasumsikan dapat mewakili populasi penelitian dan adanya kemudahan akses (Purnaini dan Utomo, 2013); 2) pengukuran dan pengujian parameter kualitas air dilakukan dengan metode analisis kualitas air yaitu DO dan BOD menggunakan analisis botol Winkler, TSS dan TDS menggunakan metode Gravimetri. Selanjtynya data 


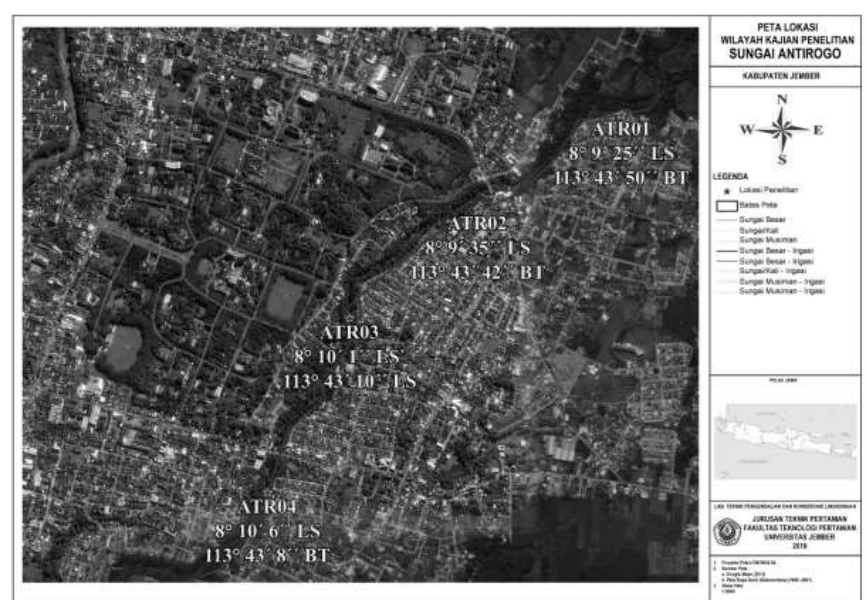

Gambar 1. Peta wilayah kajian lokasi penelitian Sungai Antirogo

kualitas digunakan untuk menghitung laju deoksigenasi, laju reaerasi, nilai defisit oksigen menggunakan persamaan Streeter and Phelps. dan nilai DO dilakukan di Laboratorium Teknik Pengendalian dan Konservasi Lingkungan (TPKL) Jurusan Teknik Pertanian Fakultas Teknologi Pertanian Universitas Jember.

Perhitungan beban pencemaran dilakukan untuk mengetahui besarnya zatpencemaryang masuk ke dalam Sungai Antirogo. Sedangkan penentuan daya tampung dilakukan dengan menggunakan metode Streeter Phelps yang bertujuan untuk mengetahui kemampuan sungai menerima beban pencemaran. Metode Streeter Phelps menghitung dua fenomena, yaitu proses pengurangan oksigen terlarut (deoksigenasi) akibat aktivitas bakteri dalam mendegradasikan bahan organik yang ada dalam air dan proses peningkatan oksigen terlarut (reaerasi) yang disebabkan turbulensi yang terjadi pada aliran sungai. Kemampuan sungai dapat diketahui dengan menghitung laju deoksigenasi, laju reaerasi, defisit oksigen kritis, jarak kritis, dan waktu yang diperlukan untuk mencapai titik kritis.

\section{Pegumpulan Data}

Metode pengumpulan data meliputi pengumpulan data sekunder (studi literatur) dan pengumpulan data primer (pengukuran crosss section, debit aliran, dan pegujian kualitas air sungai).

\section{Bahan}

Bahan yang digunakan antara lain sampel air sungai, larutan $\mathrm{MnSO}_{4}$, larutan alkali iodida azida, indikator kanji (amilum), larutan natriumtiosulfat 0,025 $\mathrm{N}$, aquades, larutan $\mathrm{H}_{2} \mathrm{SO}_{4} 6 \mathrm{~N}$, larutan $\mathrm{K}_{2} \mathrm{Cr}_{2} \mathrm{O}_{7} 0,025 \mathrm{~N}$, dan kertas saring $40 \mu \mathrm{m}$.

\section{Alat}

Alat-alat yang digunakan pada penelitian ini antara lain current meter (Universal Current Meter F1, SEBA Hydrometrie GmbH \& Co, Jerman), GPS (Garmin 72H SEA, Garmin Ltd, Amerika Serikat), pH meter (Senz pH, Trans Instruments Ltd, Singapura), oven (Universal Oven Memmert UFE 400, Memmert GmbH \& Co, Jerman), neraca analitik (Ohaus PA224, Ohaus Instruments, Cina), TDS meter (HM TDS-4, HM Digital, Amerika Serikat), dan turbiditimeter (Eutech Waterproof Portable TN-100, Eutech Instruments, Singapura).

\section{Analisis Data}

Analisis data yang dilakukan meliputi penentuan kondisi kualitas air, perhitungan beban pencemaran, dan penentuan daya tampung sungai. Kriteria yang digunakan untuk kebaikan model setelah diperoleh suatu model adalah root mean square error (RMSE). RMSE merupakan metode seleksi model berdasarkan pada error hasil estimasi. Error yang ada menunjukkan seberapa besar perbedaan hasil estimasi dengan nilai yang akan diestimasi. Nilai ini akan digunakan untuk menentukan model mana yang terbaik (Chai and Draxler, 2014). Adapun persamaan RMSE dirumuskan dalam Persamaan 1.

$$
R M S E=\sqrt{\frac{\sum_{i}^{n}=1(y i-Y i)^{2}}{n}}
$$

Berdasarkan Persamaan 1, yi merupakan nilai prediksi, Yi merupakan nilai aktual, dan jumlah sampel yang dilambangkan dengan $\mathrm{n}$.

\section{HASIL DAN PEMBAHASAN}

\section{Beban Pencemaran Sungai Antirogo}

Beban pencemaran Sungai Antirogo dapat dihitung dengan menggunakan konsentrasi BOD dikalikan debit total di setiap titik pantau. Hasil pengukuran beban pencemaran Sungai Antirogo dapat dilihat pada Tabel 1.

Tabel 1. Data hasil pengukuran debit dan konsentrasi BOD

\begin{tabular}{ccc}
\hline Titik Pantau & $\begin{array}{c}\text { Debit } \\
\text { (liter/detik) }\end{array}$ & $\begin{array}{c}\text { Konsentrasi BOD } \\
(\mathrm{mg} / \mathrm{L})\end{array}$ \\
\hline ATR01 & $1.050,18 \pm 85,33$ & $0,75 \pm 0,46$ \\
ATR02 & $942,93 \pm 184,12$ & $0,83 \pm 0,39$ \\
ATR03 & $1.148,57 \pm 80,30$ & $0,82 \pm 0,30$ \\
ATR04 & $1.009,07 \pm 94,19$ & $0,74 \pm 0,27$ \\
\hline Rata rata & $1.037,69$ & 0,79 \\
\hline
\end{tabular}




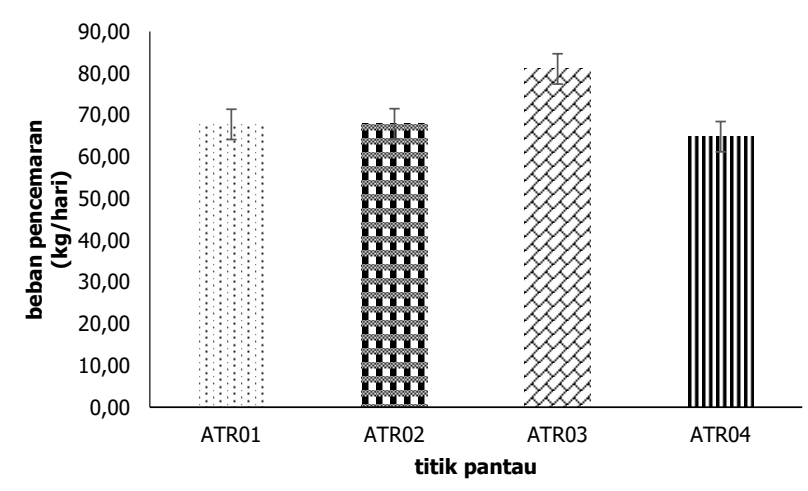

Gampar L. vata nası pengukuran Depan pencemaran sungai Antirogo

Berdasarkan Tabel 1, dapat diketahui rata-rata debit Sungai Antirogo yaitu 1.037,69 liter/detik atau 1,04 m³ detik. Menurut Welch and Lindell (1980), terdapat lima kategori arus yaitu arus yang sangat lambat (kurang dari $0,10 \mathrm{~m} 3 /$ detik $)$, lambat $\left(0,10-0,25 \mathrm{~m}^{3} /\right.$ detik $)$, sedang $\left(0,25-0,50 \mathrm{m3} /\right.$ detik), cepat $\left(0,50-1,00 \mathrm{~m}^{3} /\right.$ detik $)$, dan sangat cepat (lebih dari $1 \mathrm{~m}^{3} /$ detik). Berdasarkan Tabel 1, Sungai Antirogo termasuk kategori arus cepat yaitu berkisar 0,50-1,00 $\mathrm{m}^{3} /$ detik. Grafik beban pencemaran Sungai Antirogo dapat dilihat pada Gambar 2.

Berdasarkan Gambar 2, dapat diketahui bahwa rata-rata nilai beban pencemaran Sungai Antirogo $70,37 \mathrm{~kg} / \mathrm{hari}$. Nilai beban pencemaran tertinggi berada pada titik pantau ATR03 yaitu sebesar $81,043 \mathrm{~kg} / \mathrm{hari}$. Hal tersebut disebabkan adanya sumber pencemar non point source dan point source. Sumber menyebar (non point source) yaitu limbah pertanian dan limbah pemukiman penduduk. Sumber titik (point source) yaitu adanya limbah industri tahu yang langsung dibuang ke badan sungai, sedangkan sumber limbah pemukiman penduduk yaitu hasil aktivitas manusia, seperti membuang sampah rumah tangga, mandi, mencuci pakaian, mencuci hewan, dan buang air besar. Untuk mengurangi beban pencemaran tersebut, salah satu upaya yang dapat dilakukan yaitu membangun tempat MCK (Mandi Cuci Kakus). Adanya tempat MCK tersebut dapat mengurangi beban pencemaran. Hal ini sesuai dengan pernyataan (Salim, 2002), bahwa peran MCK dapat menurunkan beban pencemaran, apabila instalasi MCK dilengkapi dengan septic tank maka beban pencemaran dapat berkurang sebesar $40-50 \%$.

Pada titik pantau ATR04 terjadi penurunan nilai beban pencemar yaitu sebesar $64,806 \mathrm{~kg} /$ hari. Hal tersebut disebabkan adanya bebatuan kecil yang menyebabkan terjadinya turbulensi, sehingga berpengaruh terhadap oksigen di sekitar perairan tersebut. Adanya proses turbulensi dapat meningkatkan kandungan oksigen terlarut (dissolved oxygen) akibat peningkatan kontak air dengan udara. Peningkatan kontak air dengan udara tersebut menyebabkan aliran air dapat memperbaiki kualitasnya secara mandiri (Allbab dkk., 2013).

\section{Analisis Daya Tampung Beban Pencemaran Sungai Antirogo}

Daya tampung menggunakan metode Streeter Phelps menggunakan dua fenomena yaitu proses pengurangan oksigen terlarut (deoksigenasi) dan proses peningkatan oksigen terlarut (reaerasi). Deoksigenasi terjadi akibat adanya aktivitas bakteri dalam mendegradasikan bahan organik yang ada dalam air, sedangkan reaerasi terjadi akibat adanya turbulensi pada aliran sungai.

\section{Laju Deoksigenasi dan Laju Reaerasi Sungai Antirogo}

Nilai konstanta (koefisien deoksigenasi) air sungai dapat menunjukkan kecepatan penggunaan oksigen oleh air sungai untuk proses biokimia seperti dekomposisi bahan organik yang termasuk ke dalam air sungai secara biologis oleh mikroba dan proses oksidasi secara kimia. Data hasil penghitungan laju deoksigenasi dan laju reaerasi dapat dilihat pada Tabel 2. Grafik laju reaerasi dan laju deoksigenasi dapat dilihat pada Gambar 3.

Tabel 2. Data perhitungan laju deoksigenasi dan laju reaerasi

\begin{tabular}{lccrrrr}
\hline \multirow{2}{*}{$\begin{array}{c}\text { Titik } \\
\text { Pantau }\end{array}$} & ${\mathrm{Kd}\left(20^{\circ} \mathrm{C}\right)}$ & $\mathrm{KdT}$ & $\mathrm{Kr}$ & $\mathrm{KrT}$ & $\mathrm{Lt}$ & $\mathrm{D}$ \\
\cline { 2 - 7 } hari $^{-1}$ & hari $^{-1}$ & hari $^{-1}$ & hari $^{-1}$ & $\mathrm{mg} / \mathrm{L}$ & $\mathrm{mg} / \mathrm{L}$ \\
\hline ATR01 & 1,31 & 1,81 & 17,13 & 19,14 & 0,12 & 1,38 \\
ATR02 & 1,17 & 1,68 & 12,45 & 14,06 & 0,14 & 1,21 \\
ATR03 & 1,06 & 1,57 & 8,27 & 9,44 & 0,14 & 1,16 \\
ATR04 & 1,35 & 2,06 & 23,09 & 26,64 & 0,12 & 1,02 \\
\hline Rata-rata & 1,22 & 1,78 & 15,24 & 17,32 & 0,13 & 1,19 \\
\hline
\end{tabular}

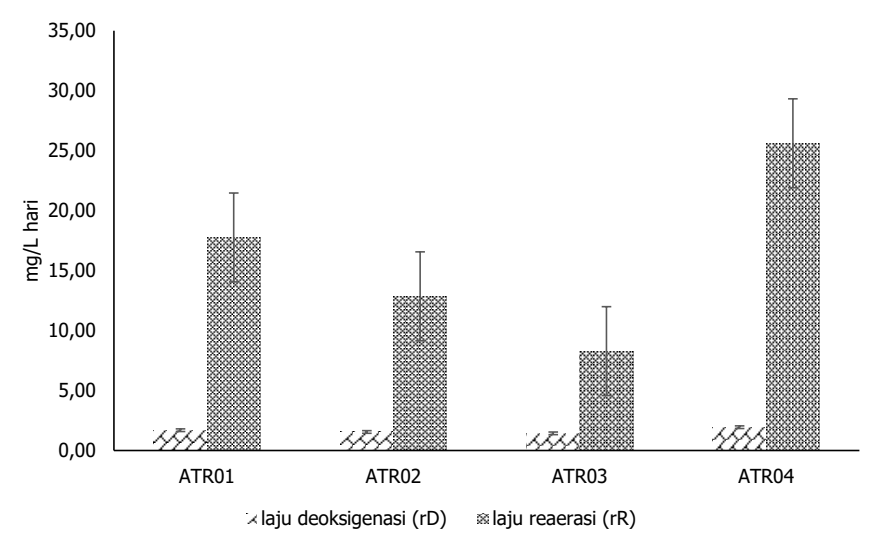

Gambar 3. Perbandingan nilai rD dan rR 
Berdasarkan Tabel 2 dan Gambar 3 dapat diketahui bahwa laju deoksigenasi (rD) berkisar antara 1,43 1,94 mg/L.hari. Laju deoksigenasi (rD) tertinggi pada titik pantau ATR04 yaitu sebesar 1,94 mg/L.hari. Nilai konstanta deoksigenasi (Kd) terbesar yaitu $1,35 \mathrm{mg} / \mathrm{L}$ dan nilai Lt terkecil yaitu sebesar 0,12 mg/L. Besarnya nilai Kd dipengaruhi oleh kedalaman sungai. Menurut (Yustiani dkk., 2018), kedalaman sungai memengaruhi kehidupan mikroba karena semakin dalam sungai, semakin rendah suplai oksigen terlarut dan sedikit mikroba yang dapat bertahan hidup pada kondisi tersebut. Berdasarkan data pengamatan, kedalaman Sungai Antirogo pada titik pantau ATR04 yaitu 0,25 m, sedangkan nilai laju deoksigenasi terkecil berada pada titik pantau ATR03 yaitu sebesar 1,43 mg/L.hari. Nilai konstanta deoksigenasi (Kd) terkecil yaitu sebesar 1,06 $\mathrm{mg} / \mathrm{L}$ dan nilai Lt tertinggi yaitu sebesar $0,14 \mathrm{mg} / \mathrm{L}$. Kedalaman pada titik pantau ATR03 yaitu sebesar 0,44 $\mathrm{m}$. Data tersebut menunjukkan titik pantau yang paling dalam.

Nilai laju reaerasi Sungai Antirogo berkisar 8,24 $25,61 \mathrm{mg} / \mathrm{L}$.hari. Nilai laju reaerasi tertinggi berada pada titik pantau ATR04 yaitu sebesar $25,61 \mathrm{mg} / \mathrm{L}$.hari. Nilai $\mathrm{Kr}$ terbesar yaitu sebesar $23,09 \mathrm{mg} / \mathrm{L}$ dan nilai defisit oksigen terkecil yaitu sebesar $1,02 \mathrm{mg} / \mathrm{L}$. Besarnya nilai $\mathrm{Kr}$ disebabkan profil hidraulik sungai banyak bebatuan kecil dan dangkal yaitu sekitar 0,25 m dan kecepatan yang relatif besar di antara semua titik yaitu $0,39 \mathrm{~m} /$ detik sehingga terjadi turbulensi yang dapat meningkatkan oksigen dan dapat mengurangi pencemaran organik. Sedangkan nilai laju reaerasi terendah berada pada titik ATR03 yaitu sebesar $8,24 \mathrm{mg} / \mathrm{L}$.hari. Hal tersebut disebabkan profil hidraulik sungai yang dalam yaitu 0,44 $\mathrm{m}$ dan kecepatan yang relatif kecil yaitu 0,28 m/detik.

Nilai defisit oksigen (D) dipengaruhi oleh DO saturasi yang nilainya berdasarkan temperatur air. Menurut Wetzel (1975), peningkatan suhu perairan menyebabkan penurunan tingkat kelarutan gasgas dalam air, termasuk oksigen. Kelarutan oksigen mempunyai hubungan terbalik dan non linier terhadap suhu. Kelarutan oksigen meningkat seiring dengan menurunnya suhu.

\section{Self Purification Sungai Antirogo}

Pemurnian alami (self purification) adalah kemampuan alam dari suatu badan air untuk membersihkan pencemar melalui proses-proses kimia, fisika, dan biologi yang berlangsung secara alami menjadi suatu zat yang stabil (Adriansyah, 2017). Kemampuan sungai untuk pulih kembali memiliki batasan. Sungai dapat pulih jika konsentrasi beban pencemar yang dikandungnya tidak mencapai batas kritis. Proses
Tabel 3. Data perhitungan self purification

\begin{tabular}{lcccccc}
\hline \multirow{2}{*}{$\begin{array}{c}\text { Titik } \\
\text { pantau }\end{array}$} & DO $_{\text {act }}$ & BOD & rD & rR & DO $_{\text {sat }}$ & $\begin{array}{c}\text { DO } \\
\text { model }\end{array}$ \\
\cline { 2 - 7 } & $\mathrm{mg} / \mathrm{L}$ & $\mathrm{mg} / \mathrm{L}$ & hari $^{-1}$ & hari-1 $^{-1}$ & hari- $^{-1}$ & $\mathrm{mg} / \mathrm{L}$ \\
\hline ATR01 & 6,59 & 0,75 & 1,69 & 17,76 & 7,97 & 6,77 \\
ATR02 & 6,67 & 0,83 & 1,54 & 12,86 & 7,88 & 6,74 \\
ATR03 & 6,63 & 0,82 & 1,43 & 8,28 & 7,78 & 6,72 \\
ATR04 & 6,67 & 0,74 & 1,94 & 25,61 & 7,69 & 6,75 \\
Rata-rata & 6,64 & 0,79 & 1,65 & 16,13 & 7,83 & 6,74 \\
\hline
\end{tabular}

akibat deoksigenasi dan reareasi menghasilkan oxygen sag curve yang menunjukkan nilai oksigen terlarut di sungai. Oxygen sag curve dapat dihitung menggunakan defisit oksigen kritis (Dc). Data hasil perhitungan self purification dapat dilihat pada Tabel 3. Grafik perhitungan self purification dapat dilihat pada Gambar 4.

Berdasarkan Tabel 3 dan Gambar 4, dapat diketahui bahwa konsentrasi pencemar (BOD) menunjukkan nilai rata-rata $0,79 \mathrm{mg} / \mathrm{L}$, rata-rata nilai laju deoksigenasi (rD) sebesar 1,65 hari-1, dan rata-rata nilai laju reaerasi (rR) sebesar 16,13 hari-1. Berdasarkan Gambar 4, dapat diketahui bahwa setiap titik pantau tidak mengalami penurunan oksigen terlarut meskipun terdapat beban pencemar yang masuk ke dalam badan sungai. Hal tersebut dapat diartikan bahwa Sungai Antirogo tidak mengalami kondisi kritis. Penyebab Sungai Antirogo tidak mengalami kondisi kritis dikarenakan nilai laju reaerasi (peningkatan oksigen terlarut) yang besar dibandingkan dengan nilai laju deoksigenasi (penurunan oksigen terlarut). Rata-rata nilai laju reaerasi (rR) Sungai Antirogo sebesar 16,13 hari $^{-1}$ sedangkan rata-rata nilai laju deoksigenasi (rD) sebesar 1,65 hari-1. Menurut Rachimi (2003), perbandingan antara laju reaerasi dengan konstanta laju penguraian disebut laju self purification. Apabila konstanta laju reaerasi lebih besar

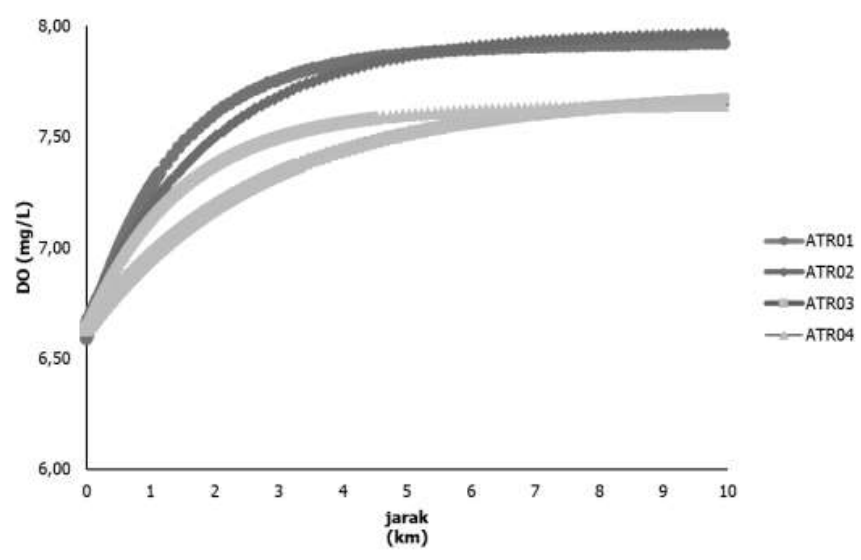

Gambar 4. Oxygen sag curve Sungai Antirogo 
dari konstanta laju penguraian, maka daya dukung perairan lebih tinggi dibandingkan dengan beban yang masuk. Jika nilai laju reaerasi lebih kecil dari konstanta laju penguraian, maka daya dukung perairan lebih rendah daripada beban yang masuk. Hal tersebut yang menyebabkan kemampuan self purification dari suatu badan perairan semakin kecil dan membutuhkan waktu yang lama.

\section{Daya Tampung Beban Pencemaran Sungai Antirogo}

Daya tampung beban pencemaran merupakan kemampuan air pada sumber air untuk menerima masukan beban pencemaran tanpa mengakibatkan air tersebut menjadi cemar (Keputusan Menteri Negara Lingkungan Hidup, 2003). Titik pantau Sungai Antirogo memiliki panjang sungai $1,5 \mathrm{~km}$ yang terbagi menjadi tiga segmen. Pembagian segmen bertujuan untuk mengetahui purifikasi dan daya tampung di setiap segmen, karena setiap segmen menggambarkan adanya masukan limbah sebelum titik tersebut mencapai DO kritis dan DO saturasi. Segmen 1 berada pada titik pantau ATR01 hingga ATR02, Segmen 2 berada pada titik pantau ATR02 hingga ATR03, Segmen 3 berada pada titik pantau ATR03 hingga ATR04. Data hasil perhitungan DO aktual $\left(\mathrm{DO}_{\text {act }}\right)$ dan $\mathrm{DO}$ model dapat dilihat pada Tabel 4. Adapun grafik nilai DO Sungai Antirogo saat adanya beban pencemar dapat dilihat pada Gambar 5.

Berdasarkan Tabel 4 dan Gambar 5, dapat diketahui bahwa nilai konsentrasi DO model berkisar $6,720-6,767 \mathrm{mg} / \mathrm{L}$ dengan nilai rata-rata $6,74 \mathrm{mg} / \mathrm{L}$. Nilai $\mathrm{DO}_{\text {act }}$ berkisar $6,59-6,67 \mathrm{mg} / \mathrm{L}$ dengan rata-rata $6,64 \mathrm{mg} / \mathrm{L}$. Rata-rata nilai defisit oksigen awal 1,19 $\mathrm{mg} / \mathrm{L}$. Nilai DO model menunjukkan berada diantara DO saturasi dan $\mathrm{DO}_{\text {act }}$. Hal tersebut dapat diartikan bahwa Sungai Antirogo pada saat air sungai menerima beban pencemar tidak sampai terjadi DO kritis, air sungai sudah melakukan purifikasi (self purification) akibat turbulensi dari aliran sungai yang besar dengan ditunjukkan nilai laju reaerasi yang besar dibandingkan laju deoksigenasinya. Berdasarkan Tabel 4, rata-rata nilai laju reaerasi (rR) sebesar 16,13 hari $^{-1}$, sedangkan nilai laju deoksigenasi (rD) sebesar 1,65 hari ${ }^{-1}$. Nilai $r R$ terbesar terdapat pada titik pantau ATR04 yaitu sebesar 25,61 mg/L.hari dengan nilai rD sebesar $1,94 \mathrm{mg} / \mathrm{L}$. hari. Nilai $r R$ terkecil terdapat pada titik pantau ATR03 yaitu sebesar $8,28 \mathrm{mg} / \mathrm{L}$.hari dengan nilai $\mathrm{rD}$ sebesar

Tabel 4. Data hasil perhitungan $\mathrm{DO}_{\text {act }}$ dan DO model

\begin{tabular}{cccccccc}
\hline Segmen & $\begin{array}{c}\text { Titik } \\
\text { pantau }\end{array}$ & $\begin{array}{c}\mathrm{DO}_{\text {act }} \\
(\mathrm{mg} / \mathrm{L})\end{array}$ & Beban & $\begin{array}{c}\text { Panjang } \\
\text { segmen }(\mathrm{km})\end{array}$ & $\begin{array}{c}\mathrm{DO} \\
\text { model }(\mathrm{mg} / \mathrm{L})\end{array}$ & $\begin{array}{c}\text { DO sat } \\
(\mathrm{mg} / \mathrm{L})\end{array}$ & $\begin{array}{c}\text { Defisit oksigen awal } \\
(\mathrm{mg} / \mathrm{L})\end{array}$ \\
1 & ATR01 & 6,59 & 67,75 & 0,4 & 6,77 & 7,97 & 1,38 \\
2 & ATR02 & 6,67 & 67,89 & 0,3 & 6,74 & 7,88 & 1,21 \\
3 & ATR03 & 6,63 & 81,04 & 0,6 & 6,72 & 7,78 & 1,16 \\
& ATR04 & 6,67 & 64,81 & & 6,75 & 7,69 & 1,02 \\
\hline Rata rata & & 6,64 & 70,37 & & 6,74 & 7,83 & 1,19 \\
\hline
\end{tabular}

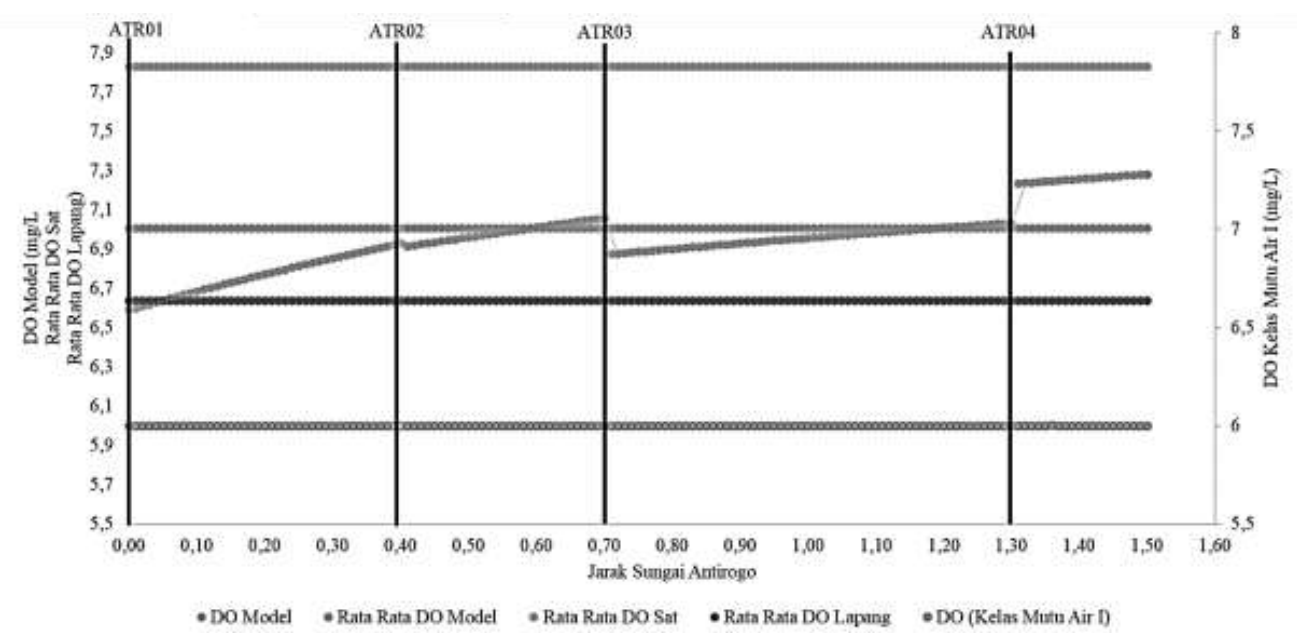

Gambar 5. Profil nilai DO Sungai Antirogo 
$1,43 \mathrm{mg} / \mathrm{L}$.hari. Meskipun nilai $\mathrm{rR}$ yang kecil tetapi berdasarkan persamaan kondisi kritis (tc) titik pantau ATR04 tidak mengalami kondisi kritis, sehingga diartikan bahwa Sungai Antirogo masih mampu menampung beban pencemar.

Nilai konsentrasi DOact berdasarkan baku mutu air sungai kelas I, II, III, dan IV masih di atas dari standar baku mutu. Selisih nilai rata-rata $\mathrm{DO}_{\text {act }}$ Sungai Antirogo dengan nilai DO kelas I yaitu sebesar 0,64 $\mathrm{mg} / \mathrm{L}$, sehingga didapatkan nilai $\mathrm{BOD}_{\text {sisa }}$ sebesar 0,08 $\mathrm{mg} / \mathrm{L}$ dan nilai beban pencemaran sisa yaitu sebesar $7,26 \mathrm{~kg} / \mathrm{hari}$. Hal tersebut dapat diartikan bahwa Sungai Antirogo meskipun menerima beban pencemar tetapi masih berada pada kondisi aman dan masih mampu menerima beban pencemar sebesar 7,26 kg/hari.

\section{KESIMPULAN}

Hasil penelitian menunjukkan bahwa rata-rata nilai laju deoksigenasi Sungai Antirogo sebesar 1,65 $\mathrm{mg} / \mathrm{L}$.hari, rata-rata nilai laju reaerasi sebesar 16,13 $\mathrm{mg} / \mathrm{L}$.hari, rata-rata nilai $\mathrm{DO}_{\text {act }} 6,64$, dan nilai beban pencemaran sisa 7,26 kg/hari. Berdasarkan tingginya nilai laju reaerasi dibandingkan dengan nilai laju deoksigenasi dan terdapat nilai beban pencemeran sisa dapat dinyatakan Sungai Antirogo tidak mengalami kondisi kritis mampu menerima beban pencemaran sebesar $7,26 \mathrm{~kg} / \mathrm{hari}$.

\section{UCAPAN TERIMA KASIH}

Ucapan terima kasih kami sampaikan kepada Program Hibah Penelitian Keris Batch 2, Universitas Jember tahun 2019. Ucapan terima kasih kepada Ketua Laboratorium Teknik Pengendalian dan Konservasi Lingkungan, Teknik Pertanian, Universitas Jember, atas izinnya dalam menggunakan alat laboratorium untuk keperluan pengujian sampel.

\section{KONFLIK KEPENTINGAN}

Dalam penelitian ini mulai dari pengambilan sampel di lapang dan dilakukan analisis di laboratorium serta penyusunan laporan tidak terdapat konflik kepentingan.

\section{DAFTAR PUSTAKA}

Adriansyah, R. (2017). Peranan Ruang Terbuka Hijau dalam Purifikasi Sungai Ciliwung Segmen Cilebut Timur, Kabupaten Bogor (Institut Pertanian Bogor). http:// repository.ipb.ac.id/handle/123456789/89931
Allbab, Ulill, Dermawan, Very, Harisuseno, D. (2013). Studi Analisis Nilai Sebaran Kadar Oksigen Terlarut Dalam Aliran (Do) Pada Hulu Dan Hilir Bangunan Bendung Di Daerah Irigasi Tumpang Kabupaten Malang. Jurnal Fakultas Teknik Universitas Brawijaya, 12(1), 23. http:// pengairan.ub.ac.id/s1/wp-content/uploads/2016/01/ Studi-Analisis-Nilai-Sebaran-Kadar-Oksigen-Terlarutdalam-Aliran-DO-pada-Hulu-dan-Hilir-BangunanBendung-di-Daerah-Irigasi-Tumpang-Kabupaten-Malang-Ulill-Allbab-105060407111003.pdf

Astono, W. (2010). Organik ( Kd ) Dan Nilai Konstanta Reaerasi. II (1).

Chai, T., \& Draxler, R. R. (2014). Root mean square error (RMSE) or mean absolute error (MAE)? -Arguments against avoiding RMSE in the literature. Geoscientific Model Development, 7(3), 1247-1250. https://doi. org/10.5194/gmd-7-1247-2014

Desy Darmasusantini, P., Merit, I. N., \& Sila Dharma, I. G. . (2015). Identifikasi Sumber Pencemar Dan Analisis Kualitas Air Tukad Saba Provinsi Bali. ECOTROPHIC: Jurnal Ilmu Lingkungan (Journal of Environmental Science), 9(2), 57. https://doi.org/10.24843/ejes.2015. v09.i02.p10

Hastono, S. P. (2007). Modul Analisis Data. Jakarta: Universitas Indonesia.

Keputusan Menteri Negara Lingkungan Hidup. (2003). Pedoman Penetapan Daya Tampung Beban Pencemaran Air.

Rachimi. (2003). Beban Bahan Organik dan Kemampuan Self Purification Sungai Jawi di Pontianak (Institut Pertanian Bogor). http://repository.ipb.ac.id/ handle/123456789/7673

Rizki Purnaini, Kiki Prio Utomo, N. S. R. (2013). Analisis Sebaran Oksigen Terlarut Saluran Sungai Jawi. Jurnal Teknologi Lingkungan Lahan Basah, 1(1), 1-10. https:// doi.org/10.26418/jtllb.v1i1.2110

Salim, H. (2002). Beban Pencemaran Limbah Domestik dan Pertanian di DAS Citarum Hulu. Jurnal Teknologi Lingkungan, 3(2), 107-111. Retrieved from http://www. kelair.bppt.go.id/Jtl/2002/vol3-2/04cemar.pdf

Suma, N. (2018). Tinjauan Karakteristik Muara Sungai Dalam Rangka Pengelolaan Perairan Pesisir Terpadu di Kabupaten Jember (IAIN Jember). http://lpm.iainjember.ac.id/download/file/Diskusi_Periodik_Obi.pdf

Welch, E. B., Lindell, T. (1980). Ecological Effects of Waste Water. London: Cambridge University Press.

Wetzel, R. G. (1975). Lymnology. Philadelphia Pensylvania: WB Saunders Co.

Yustiani, Y. M., Wahyuni, S., \& Alfian, M. R. (2018). Investigation on the deoxygenation rate of water of cimanuk river, Indramayu, Indonesia. Rasayan Journal of Chemistry, 11(2), 475-481. https://doi.org/10.7324/ RJC.2018.1121892 